The larger doses also produced dyspepsia and a sensation of burning in the mouth which persisted for 24 hours. ${ }^{13}$ Despite methylene blue's potential to cause diverse anti-inflammatory and physiologic effects, ${ }^{14,15}$ we were unable to detect any significant toxicity in our patient.

1 Kilbourn RG, Jubran A, Gross SS, et al. Reversal of endotoxin-mediated shock by $\mathrm{N}^{\mathrm{G}}$-methyl-L-arginine, an inhibitor of nitric oxide synthesis. Biochem Biophys Res Commun 1990; 172: 1132-8.

2 Kilbourn RG, Cromeens DM, Chelly FD, Griffith OW. $\mathrm{N}^{\mathrm{G}}$-Methyl-L-arginine, an inhibitor of nitric oxide formation, acts synergistically with dobutamine to improve cardiovascular performance in endotoxemic dogs. Crit Care Med 1994; 22: 1835-40.

3 Schneider F, Lutun PH, Hasselmann M, Stoclet JC Temple JD. Methylene blue increases systemic vascular resistance in human septic shock. Intensive Care Med 1992; 18: $309-11$.

4 Gachot B, Bedos JP, Veber B, Wolff M, Regnier B. Shortterm haemodynamic effects of methylene blue in refractory septic shock. Intensive Care Med 1994; 20: (suppl 2)S10 (Abstract)

5 Preiser JC, Lejeune P, Roman A, et al. Methylene blue administration in septic shock: a clinical trial. Crit Care Med 1995; 23: 259-64.

6 Daemen-Gubbels CRGH, Groeneveld PHP, Groenveld ABJ, van Kamp GJ, Bronsveld W, Thijs LG. Methylene blue increases myocardial function in septic shock. Crit Care Med 1995; 23: 1363-70.

7 Burrows GE. Methylene blue: effects and disposition in sheep. F Vet Pharmacol Ther 1984; 7: 225-31.

8 Blass N, Fung D. Dyed but not dead - methylene blue 8 Blass N, Fung D. Dyed but not dead -
overdose. Anesthesiology 1976; 45: 458-9.
Based on the short-term haemodynamic benefits of methylene blue in septic shock, we would encourage investigators to consider more prolonged administration of the drug. Data on benefit and absence of toxicity can only be obtained through increased investigation.

9 Greutter CA, Kadowitz PH, Ignarro LJ. Methylene blue inhibits coronary arterial relaxation and guanylate cyclase activation by nitroglycerin, sodium nitrite, and amyl nitrite. Can $\mathcal{F}$ Physiol Pharmacol 1981; 59: 150-6.

10 Johnstone MT, Lam JYT, Lacost L, Baribeau J, Theroux P, Waters D. Methylene blue inhibits the antithrombotic effect of nitroglycerin. F Am Coll Cardiol 1993; 20: 255-9.

11 Lusche W, Bosua A, Hekker R, Pescarmona GP, Arese P, Till U. Methylene blue inhibits the arachidonic acid metabolism in human blood platelets. Biomed Biochim Acta 1988; 47 (suppl):S100-S103.

12 Sloand EM, Kessler CM, McIntosh CL, Klein HG Methylene blue for neutralization of heparin. Thromb Res 1989; 54: 677-686.

13 Nadler JE, Green $H$, Rosenbaum A. Intravenous injection of methylene blue in man with reference to its toxic symptoms and effect on the electrocardiogram. $\mathrm{Am} \mathcal{F} \mathrm{Med}$ Sci 1934; 188: 15-21.

14 Culo F, Sabolovic D, Somogyi L, Marusic M, Berbiguier N, Galey L. Anti-tumoral and anti-inflammatory effects of biological stains. Agents Actions 1991; 34: 424-8.

15 Torres M, Ceballos G, Rubio R. Possible role of nitric oxide in catecholamine secretion by chromaffin cells in the presence and absence of cultured endothelial cells. $\mathscr{f}$ Neurochem 1994; 63: 988-96.

\title{
Cushing's syndrome due to autonomous macronodular adrenal hyperplasia: long-term follow-up after unilateral adrenalectomy
}

\author{
Mauro Boronat, Tomás Lucas, Balbino Barceló, Carmen Alameda, Hassan Hotait, \\ Javier Estrada
}

\section{Summary \\ This report describes a case of Cushing's syndrome due to autonomous macronod- ular adrenocortical hyperplasia in which unilateral resection of the right adrenal resolved the Cushing's syndrome.}

Keywords: Cushing's sydrome, suprarrenal hyperplasia, adrenalectomy

Clinica Puerta de

Hierro, C/San Martín

de Porres 4, 28035

Madrid, Spain

Department of

Endocrinology

M Boronat

T Lucas

B Barceló

C Alameda

J Estrada

Pathology Services

H Hotait

Accepted 12 January 1996
Endogenous adrenocorticotropin (ACTH)independent Cushing's syndrome is caused by an autonomous adrenal production of cortisol. In most cases, it is due to a primary adrenal neoplasm, adenoma or carcinoma, usually unilateral. Rare nontumourous primary adrenal processess that can also cause Cushing's syndrome are bilateral. They include pigmented micronodular adrenal dysplasia ${ }^{1}$ and autonomous macronodular adrenocortical hyperplasia (AMAH). ${ }^{2-4}$ We describe a patient with AMAH who was treated successfully by unilateral adrenalectomy.

\section{Case report}

In 1984, a 53-year-old man presented with weakness, weight gain, easy bruising and impotence, which had developed over a period of two years. He had a history of chronic obstructive pulmonary disease, heart failure and mixed angina, and was known to have been hypertensive for 10 years. On physical examination, the patient was found to have cushingoid appearance, with centripetal obesity, atrophic skin and ecchymoses on forearms.

Endocrine assessment is summarised in the table. Computed tomography (CT) of the turcica sella was normal. Abdominal CT revealed a tumour mass occupying the entire right adrenal gland. The contralateral gland was also enlarged and contained a focal nodule localised in its central portion (figure 1). Scanning with ${ }^{131}$ I-labelled cholesterol demonstrated bilateral but asymmetrical uptake of the tracer, indicating much greater activity on the right arm than on the left gland (figure 2). 
Figure 1 Abdominal CT imaging. Bilateral but asymmetrical diffuse enlargement of adrenal glands. Note a small nodular image inside the left gland

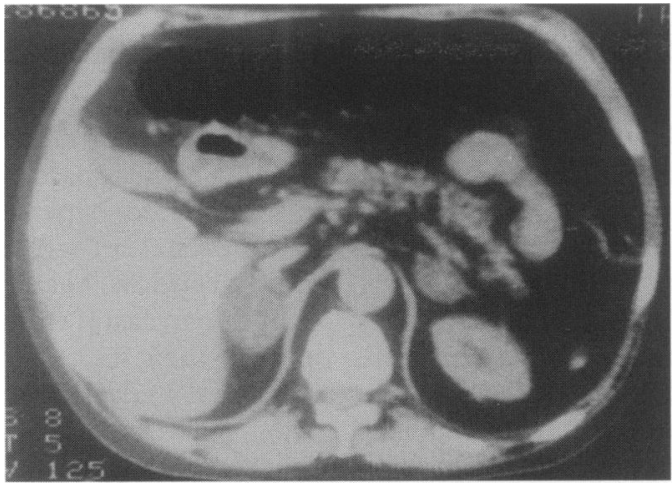

Figure 2 Scanning of the adrenals with ${ }^{131}$ iodocholesterol. Uptake of the tracer is bilateral but considerably more marked on the right

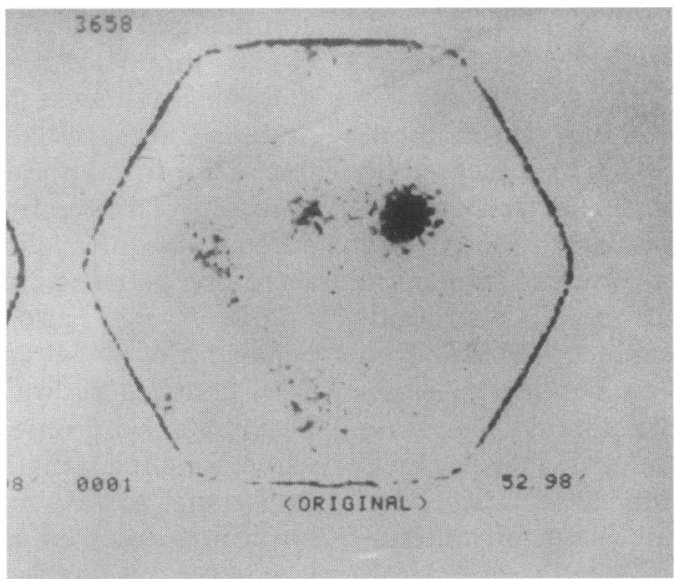

With the diagnosis of $A M A H$, the patient underwent right adrenalectomy. Owing to the concurrent history of cardiac and pulmonary diseases, bilateral adrenalectomy was considered to entail high risk and resection of the other gland was delayed for a further operation.

The adrenal gland weighed $26.8 \mathrm{~g}$ and measured $5.5 \times 4.5 \times 3 \mathrm{~cm}$. Light microscopic examination revealed well-delimited benign hyperplastic nodules, which ranged in size from microscopic clusters of cells to $2 \mathrm{~cm}$ in diameter. The internodular areas of the cortex did not show atrophy, but were also occupied by diffusely hyperplastic tissue.

Postoperatively, baseline plasma cortisol was $377.3 \mathrm{nmol} / 1 \quad(08.00 \mathrm{~h})$ and $470.9 \mathrm{nmol} / 1$ $(23.00 \mathrm{~h})$, urinary free cortisol was $126.9 \mathrm{nmol} / 24 \mathrm{~h}$ and serum ACTH levels were undetectable. Signs and symptoms of hypercortisolism resolved some months later.

Although baseline plasma cortisol and urinary free cortisol always ranged within normal limits, studies of adrenocortical function at three, six and 12 months postsurgery, and
Cushing's syndrome: classification and management

ACTH-dependent

- Cushing's disease: transsphenoidal surgery

- ectopic ACTH-secreting tumour: surgical resection (medical therapy if surgery not possible)

\section{ACTH-independen}

- adrenal tumour: ipsilateral adrenalectomy

- pigmented micronodular dysplasia: bilateral simultaneous adrenalectomy

- AMAH: bilateral adrenalectomy (evaluating unilateral adrenalectomy if adrenals are asymmetrical)

\begin{tabular}{|l|}
\hline Summary points \\
\hline $\begin{array}{l}\text { Cases of AMAH (especially if asymmetrical } \\
\text { hyperplasia occurs) could be treated by removal } \\
\text { of the most hyperplastic adrenal, performing a } \\
\text { delayed contralateral adrenalectomy only if } \\
\text { hypocortisolism recurs }\end{array}$ \\
\hline
\end{tabular}

annually thereafter, continued to demonstrate persistent loss of cortisol rhythm, without suppression by high doses of dexamethasone. When last seen at the follow-up clinic, 10 years after adrenalectomy, basal plasma cortisol was $198.2 \mathrm{nmol} / 1 \quad(08.00 \mathrm{~h})$ and $187.6 \mathrm{nmol} / 1$ $(23.00 \mathrm{~h})$, plasma ACTH was $1.23 \mathrm{pmol} / \mathrm{l}$ $(08.00 \mathrm{~h})$ and $1.07 \mathrm{pmol} / \mathrm{l}(23.00 \mathrm{~h})$ and urinary free cortisol was $96.5 \mathrm{nmol} / 24 \mathrm{~h}$. After overnight $16 \mathrm{mg}$ oral dexamethasone adminstration, the morning plasma cortisol level was $204.1 \mathrm{nmol} / \mathrm{l}$. Baseline plasma 11-deoxycortisol was $79.1 \mathrm{nmol} / \mathrm{l}$ and, $8 \mathrm{~h}$ after metyrapone administration, only rose to $329 \mathrm{nmol} / 1$.

\section{Discussion}

Bilateral macronodular enlargement of the adrenals develops in $20-40 \%$ of patients with Cushing's disease ${ }^{5}$ and is thought to be caused by chronic hypersecretion of ACTH. However, a few cases of AMAH without a previous history of Cushing's disease have been convincingly documented. ${ }^{2-4}$

In our patient, dynamic tests of adrenal function, suppressed ACTH levels and scintigraphic image suggested an autonomous adrenal hyperfunction. A diagnosis of AMAH was confirmed at pathological examination.

Table Pituitary-adrenocortical functional assessment

\begin{tabular}{lllll}
\hline & Baseline levels & $\begin{array}{l}2 \text { mg dexamethasone } \\
\text { suppression }\end{array}$ & $\begin{array}{l}8 \text { mg dexamethasone } \\
\text { suppression } \dagger\end{array}$ & $\begin{array}{c}\text { Metyrapone test } \\
\text { (prelpost) } \ddagger\end{array}$ \\
\hline $\begin{array}{l}\text { Plasma cortisol } \\
(\text { nmol/1) }\end{array}$ & $510.4-499.3^{\star}$ & 620.7 & 786.3 & - \\
$\begin{array}{l}\text { Urinary free cortisol } \\
(\text { nmol/24 h) }\end{array}$ & 804.2 & 662.4 & 1445.7 & $-/ 190.9$ \\
$\begin{array}{l}\text { Urinary 17-hydroxycortico- } \\
\text { steroids }(\mu \mathrm{mol} / 24 \mathrm{~h})\end{array}$ & 65.7 & 44 & 69.8 & $65.1 / 48.3$ \\
ACTH (pmol/1) & undetectable & - & - & - \\
\hline
\end{tabular}

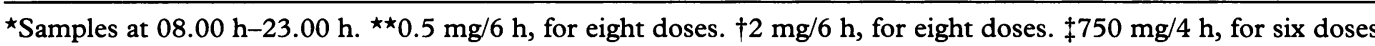


Since AMAH affects both glands, bilateral adrenalectomy appears to be the most appropriate and, to date, ${ }^{3}$ the only procedure to achieve surgical cure. Unexpectedly, in our case, a single adrenalectomy proved to be a successful treatment: cortisol secretion was reduced and the physical features of the patient regressed over subsequent months. During long-term follow-up hypercortisolism has never recurred and he is presently doing well. Postoperative outcome has revealed the remaining gland works autonomously, but it is not able to cause hypercortisolism. This striking functional profile persists 10 years after adrenalectomy.

It has been speculated that AMAH originates from a long-lasting stimulation by ACTH, ultimately becoming autonomous and suppressing pituitary ACTH release, on the basis of cases of single adrenal macronodules and coexisting pituitary lesions. ${ }^{6} \mathrm{We}$ can find no evidence of this 'transition hypothesis' to explain our case. Other noncorticotropin factors can induce AMAH. Two cases have been shown to be due to inappropriate sensitivity of the adrenal glands to gastric inhibitory polypeptide. ${ }^{7,8}$ Likewise, local growth promoting factors have also been reported to exert a mitotic effect on adrenocortical cells in vitro. ${ }^{9}$

1 Young WJ, Carney JA, Musa BU, Wulffraat NM, Lens JW, prexhage HA. Familial Cushing's syndrome due to primary 50 years later. $N$ Engl f Med 1989; 321: $1659-64$.

2 Malchoff CD, Rosa J, Debold CR, et al. Adrenocorticotropin-independent bilateral macronodular adrenal hyperplasia: an unusual cause of Cushing's syndrome $\mathfrak{f}$ Clin pisia: an unusual cause of Cetab 1989; 68: 855-60.

3 Lieberman SA, Eccleshall TR, Feldman D. ACTH-independent massive bilateral adral subtype of Cushing's syndrome with major diagnostic and therapeutic implications. Eur f Endocrinol 1994; 131: 67 73.

4 Cheitlin RA, Westphal M, Cabrera CM, Fujii DK, Snyder J Fitzgerald PA. Cushing's syndrome due to bilateral adrena macronodular hyperplasia with undetectable ACTH: cell culture of adenoma cells on extracellular matrix. Horm Res 1988; 29: $162-7$.

5 Smals AG, Pieters GF, Van Haelst UJ, Kloppenborg PW.

Macronodular adrenocortical hyperplasia in long-standing Cushing's disease. 7 Clin Endocrinol Metab 1984; 58: 25-31.
Whichever the responsible growth factor in our case (systemic or paracrine), it prompted different reactions in each gland. It produced a more intense proliferative response in the right gland, with maintenance of autonomous, differentiated hypersecretion. In contrast, the left adrenal progressed to autonomous but normal-to-low secretion, perhaps suggesting that hyperplastic cells from that gland had lost part of their functional capacity.

Clonal analysis in several macronodules from a patient with $A M A H$, demonstrated that all the nodules of a gland had a monoclonal composition, whereas those removed from the larger contralateral gland had an intermediate polyclonal-monoclonal pattern. ${ }^{10}$ Moreover, studies in vitro showed that one of the monoclonal nodules only secreted cortisol precursors, while one of the mixed nodules was still able to secrete cortisol. ${ }^{10}$ This report showed that, in AMAH, adrenal nodules display not only variable secretory patterns, but also different genetic origin. It may also explain the discordant behaviour of the adrenal glands in our patient.

In conclusion, we describe a patient with Cushing's syndrome caused by AMAH in whom a right adrenalectomy removed the most important source of corticoids. Cushing's syndrome resolved and replacement therapy was never necessary.

6 Hermus AR, Pieters GF, Smals AG, et al. Transition from pituitary-dependent to adrenal-dependent Cushing's syndrome. N Engl f Med 1988; 318: 966-70.

7 Reznik Y, Allali-Zerah V, Chayvialle JA, et al. Fooddependent Cushing's syndrome mediated by aberran adrenal sensitivity to gastric inhibitory polypeptide. $N$ Engl f Med 1992; 327: 981-6.

8 Lacroix A, Bolté E, Tremblay J, et al. Gastric inhibitory polypeptide-dependent cortisol hypersecretion. A new cause of Cushing's syndrome. N Engl f Med 1992; 327: 974-80.

9 Mesiano S, Mellon SH, Jaffe RB. Mitogenic action, Mesiano S, Mellon SH, Jaffe RB. Mitogenic action, the human fetal adrenal gland. 7 Clin Endocrinol Metab 1993 76: $968-76$.

10 Gicquel C, Leblond-Francillard M, Bertagna X, et al. Clonal analysis of human adrenocortical carcinomas and secreting adenomas. Clin Endocrinol 1994; 40: 465-77. 